\title{
A Vez da Reforma Administrativa
}

O estribilho predileto hoje é a necessidade de se proceder às chamadas "reformas de base". Destas, as mais citadas, as consideradas mais instantes são a "reforma agrária" e a "estabiliza ção do cruzeiro" ou "contenção da inflação". A reforma agrária preveniria crises de abastecimento e introduziria novos elementos de equilibrio na sociedade brasileira. Se levada a efeito sob me dida para o Brasil, teria reflexos na produção de bens e na distribuição dos benefícios econômicos. As desigualdades de renda entre as diferentes camadas sociais e as oscilações de renda das rlosses menos favorecidas, por exemplo, poderiam ser grande. mente mitigadas por meio de uma reforma agrária bem formulada ¿ bem administrada.

The forgotten man, "o homem esquecido" foi o rótulo famoso com que o Presidente Franklin Roosevelt batizou certa vez o agricultor. No Brasil, o homem esquecido é também o agricultor, especialmente o trabalhador rural assalariado, que lavra terras alheias.

Segundo o consenso geral, a reforma agrária virá opulentar - magro quinhão do pequeno lavrador, do meeiro, do trabalhador rural ambulante.

A contenção da inflação, por sua vez, refletir-se-ia prontamente na alta do custo-de-vida, anulando o mais ativo fermento de desassossêgo social em atuação no Brasil. Mas, cumpre conter a inflação não apenas para evitar precipitados sociais de conseqüiências imprevisiveis. Cumpre contê-la principalmente para pror teger o homem brasileiro, a criança brasileira, a familia brasileira contra as injustiças e crueldades decorrentes da alta desabalada do custo-de-vida. No grau a que já chegou no Brasil, a inflação é causa de males coletivos desnecessários e evitáveis, que afetam a grande maioria do povo. 
A disciplinação das remessas de lucros auferidos no Brasil por capitais e grupos estrangeiros, a cristalização da politica exterior do Brasil, pais que começa a emergir, ao lado da Índia, da Austrália e do Canadá, como potência média cada vez mais influente, a fixação definitiva do Govêrno Federal em Brasilia, a iegularização do abastecimento de gêneros alimenticios aos grandes centros urbanos, notadamente ao Rio e São Paulo, a confirmação do regime parlamentarista ou a volta ao presidencialismo pela via do plebiscito - todos êstes problemas também estão, por assim dizer, na pauta nacional, reclamando solução. Causam vigílias aos lideres politicos e sacodem a opinião pública.

Inquestionàvelmente, essa lista compreende alguns dos problemas mais prementes com aue o Brasil se vê a braços no momento. Falta, porém, acrescentar um, no qual, aliás, se está noltando a falar nestes últimos tempos, sobretudo a propósito da stibstituição do primeiro Conselho de Ministros: a reforma administrativa.

E' preciso fazê-la com urgência. E' preciso fazê-la com realismo. E' preciso fazê-la com sabedoria.

A máquina administrativa com que o Govêrno da União conta para enfrentar as mil e uma responsabilidades que o assoberban é inadequada, anárquica e obsoleta. Mutitas das crises, grandes e pequenas, que ùltimamente têm abalado os Podêres Públicos, emanam da incompetência e da ineficiência da administração pública. Sabe-se que é muito difíicil julgador a inf̣lação -- mas um sistema administrativo bem articulado, sob o comando de homens capazes e esclarecidos, conduziria o cruzeiro para a estabilidade e controlaria a corrida dos preços em menos de doze meses. Outro exemplo: é difícil fazer a reforma agrária. Dificil, porém, porque não se trata apenas de votar uma lei, mas especialmente de implementar, isto é, de executar, de administrar a reforma. E que é o problema do abastecimento, se não um probiema de natureza administrativa, e que somente por via administrativa poderá ser resolvido?

O Brasil possui, em abundância, os ingredientes de cultura e civilização com que outros paises construiram ou estão construindo a propria grandeza. Senão, vejamos: somos um país continental, - quinto do mundo em área, somos o oitavo em população, temos 
um tertitório bem aquinhoado de riquezas naturais, matérias-primas, rios, florestas, terras cultiváveis, vários tipos de clima. Já somos, também, o pais mais industrializado da América Latina. $\mathrm{Na}$ arcuitetura, no urbanismo, na pintura, na música, na literatura, na medicina, na física, nos esportes e em outros campos de atividade, o Brasil está aparecendo como nôvo astro nos horizontes do mundo - o Brasil está adquirindo e afirmando uma personalidade internacional cada vez mais nitida, que os demais paises já năo podem ignorar. Em suma, a conjuntura brasileira favorece a ¡recipitação daquilo a que a imprensa tem chamado "nossa emancipação econômica" e que simboliza o ideal da atual geração de brasileiros.

Dentre as debilidades, inadequação e arcaismo, de que c Pais se deve desvencilhar, para acelerar o ritmo de seu desenvolvimento econômico e social, e resolver bem, um a um, os chamados prob́lemas nacionais, de acôrdo com uma escala de prioridade selecionada realisticamente, destaca-se o atual sistema administrativo. A estrutura, o funcionamento, os métodos de trabaiho, a própria ambiência do serviço público brasileito - em todos os niveis de govêrno - devem ser revistos, atualizados, modernizados, mediante uma reforma corajosa, urgente e profunda.

Tem-se aventado a hipótese de o Congresso Nacional delegar ao Conselho de Ministros a tarefa de proceder à reforma do sistema administrativo federal.

Se o Conselho de Ministros solicitar e obtiver esta delegação, valendo-se pela primeira vez do instituto previsto, no artigo 22 do Ato Adicional, a reforma administrativa por que há tanto tempo - Pais anseia poderá ser formulada e adotada em quatro semanas. IVão haverá qualquer risco para o regime. Ao contrário: suas instituições serão fortalecidas, tornando-se aptas a habilitar o Govê:no a funcionar melhor e mais econômicamente. Por outro lado, não se trata de experiência aventurosa, inédita, de resultados imprevisiveis - mas de recurso já pôsto em uso em outros paises, inclusive nos Estados Unidos da América.

Apesar de o regime de govêrno adotado naquele pais ser o protótipo do presidencialismo, e não obstante a inflexibilidade tradicional, quase feroz, com que o Congresso Americano mantém e defende as suas prerrogativas e podêres, por duas vêzes, em 
épocas recentes - uma no Govêrno do Presidente Harry TRUMAN, outra no Govêrno do Presidente Dwight Eisenhower, se procecieu a reforma administrativa de envergadura na engrenagem fecleral americana, mediante delegação idêntica à que agora podetá ser concedida ao Conselho de Ministros, com base na Emenda Constitucional $n^{\circ} 4$, que substituitu no Brasil o regime presidencialista por um regime neoparlamentar sui generis. 